\title{
THE SUPREME COURT AND THE PROTECTION OF CIVIL LIBERTIES: COMMENTARY
}

THE RT. HON. BORA LASKIN, CHIEF JUSTICE OF CANADA

(The following is the text of Chief Justice Laskin's response to the two preceding papers, given by Professor Tarnopolsky and Professor Scott. The Chief Justice's introductory remarks have been deleted. - Eds.)

I've had the advantage of seeing in advance the two papers that were presented this morning. Professor Tarnopolsky and Professor Scott have each written lengthy and scholarly papers. Each paper bears the title The Supreme Court And Civil Liberties, but there the resemblance between the two papers ends. Professor Scott, and I hope I don't do him an injustice, seems to see civil liberties as consisting of a constitutionally guaranteed access to the ordinary courts, whether by prerogative writ or for damages or other remedy, to challenge excesses of jurisdiction, to vindicate abuses of executive authority, with only the ordinary courts, and not the legislatures, or at least not the provincial legislatures, being entitled to set limits to jurisdictional review. Now I would not myself have seen this kind of assessment, which takes off from Roncarelli v. Duplessis, and ends with our judgments in Lafleur and Chicoutimi as bringing civil liberties into focus. But, of course, it is all a matter of definition, and he's surely entitled to define or classify his chosen issues as he pleases. It's perhaps a bit unfortunate that there is not much common ground between Professor Tarnopolsky and Professor Scott, saving some of the things that Professor Scott added by way of oral supplement.

Professor Tarnopolsky speaks in more traditional terms, in a more traditional idiom. We have from him an assessment of the interpretative and the constitutional aspects of the familiar freedoms, and an excursion as well into the features and the problems of that quasi-constitutional document, the Canadian Bill of Rights. Of course, Professor Tarnopolsky is no stranger to the subject, as we all know his book, and we all know how deeply he has thought about the political and legal freedoms. As I read his paper, he is concerned that the courts, and particularly the Supreme Court, should not whittle down the substantive guarantees that he sees in both constitutional limitations and in the positive enactments of the Canadian Bill of Rights. At the risk of oversimplification, Professor Scott's paper strikes me as reflecting the view that procedural reviewing authority must be guaranteed because the courts will in the course of review gives substance to individual liberty by the exercise of a reviewing power, while Professor Tarnopolsky is apprehensive that the substance reflected in legislation, such as the Canadian Bill of Rights, should not be whittled down by the courts.

Ladies and gentlemen, anybody who has read Professor Tarnopolsky's paper will have realized that I am certainly a very poor choice to be a commentator on it. It's difficult indeed, and in fact it would be very churlish of me, to quarrel with approbation of one's own views! And so I shall simply not do so. There will be time for adequate discussion, I hope, and I shall listen to it very carefully. There are some features of the paper on which I would like to comment briefly. Although Professor Tarnopolsky is concerned with the Supreme Court, inevitably he had to bring into account certain decisions of the Privy Council under his heading of Egalitarian Liberties. It is very tempting for me, tempting in the extreme, (and it's not only a question of self restraint but $I$ also have a restraining influence in the presence of my brother Pigeon,) to say something about Union Colliery, and Cunningham, and Quong Wing. But, unfortunately for anything I might care to say, there is now pending for decision in our court the 
case of Morgan v. Attorney General of Prince Edward Island, the P.E.I. case which involves legislative limitations on land holding by non-residents. The trinity of cases that I have mentioned, which Professor Tarnopolsky has canvassed in such an extensive and careful manner, were brought to our attention; they were thoroughly argued in the Morgan case and I must perforce therefore say nothing about their respective merits. The only yielding to temptation which I am prepared to do is to say that there is a sort of a "Russell v. The Queen" ring about Union Colliery v. Bryden because you remember that Russell v. The Queen has been explained and extinguished and stood on its head and then set somewhat right up again and reformulated. Union Colliery seems to partake somewhat of that character, but whether like Russell, Union Colliery will rise in Morgan from the ashes, so to speak, remains a question on which I can certainly give no answer, certainly not today. So I want to pass to Professor Tarnopolsky's discussion of Christie v. York and like cases, in which he obviously felt that the court missed the chance of proving that creativity can go hand in hand with a libertarian approach. The legislative responses to the problems which the cases did not solve but could have, according to Professor Tarnopolsky, went of course far beyond the cases.

Human rights legislation and anti-discrimination legislation, as he has told us, are now general across the country. And I don't really wish to subtract from what he said about the Alberta Press case, but insofar as it represents a decision on the allocation of legislative power and the relation of such power to civil liberties and to political liberties, it must still be gauged or assessed. He told us that, by reference to what the court said in connection with Saumur, but surely we have not yet determined, saving what my former brother Abbott said in Switzman, where legislative authority effectively lies with respect to each of the political and personal freedoms which Professor Tarnopolsky canvassed. From this point of view, it can rightly be said, I think, that the Parliament of Canada sought to finesse the question by its enactment of the Canadian Bill of Rights; and it remains yet to be resolved on a power allocation basis. Provincial legislatures, it seems to me, have also finessed the question by their enactment of what might be called mini-Bills of Rights. And to a degree it may be said that Switzman gave an answer to the power allocation issue; but one wonders whether an answer which depends on the very wide view of the criminal law power, can be a sufficient resolution of this very, very important issue.

Notwithstanding that Professor Scott's paper threw me somewhat off my balance and stride, I understood it, but I can't say much about it specifically in terms of a civil liberties focus. I do however, want to say a couple of things about it before I sit down. There is a reference in it to Pringle v. Fraser. I'm bound to say from the way I read our cases - and that may not be the way you read our cases - that it was not so much that the Immigration Appeal Board was given exclusive jurisdiction respecting orders of deportation, as that a complete code of procedure has been established under immigration legislation, giving reviewing power to the board, to the Federal Court and ultimately to the Supreme Court of Canada, (we said,) to the exclusion of provincial courts. Now just last week - and perhaps most of you will not have had any notice of the decision, because it was a case that we disposed of from the Bench, important as the case was - but just last week, we applied Pringle v. Fraser in a wider, implication. We applied it to a defective order of the British Columbia Securities Commission which was challenged by certiorari instead of by a statutory right of appeal which was wide open under legislation which contained a fairly strong privative clause; and we held unanimously that the combination of the very wide right of appeal, with a full dispositive power in the court of appeal to correct errors of any sort, and the concurrent existence of a privative clause, were enough to oust review by certiorari, even in respect of a provincial court, and without 
regard to any conflict of jurisdiction between a provincial court and a federal agency or a federal court.

I'm in the stage now ladies and gentlemen, of resisting temptations. I've resisted one or two already and now I've got to resist another one: to resist or restrain any temptation to enter the lists in respect of Professor Scott's assessment of the relation between section 96 and privative clauses. Section 96 is an old bedmate of mine and Professor Scott has provided some challenging illustrations of how to make the line between unchallengable board and Superior Court disappear. But I think it important to remember that the immunity of Superior Courts from challenge to their jurisdiction, except by appeal, is largely a common law determination and it appears to me at any rate as I read that part of the paper, which is a very fascinating part of the paper, it appears to me that he is contending that this has been constitutionalized; and moreover, that Superior Courts cannot be deprived of their superintending authority over other tribunals. Now, whether the two things are the same, I'm not sure, because if rights of appeal can be denied, why not superintending power? I only raise these questions because, heaven knows, that we may be called upon to answer some of them and I might as well talk to myself for a few minutes, ask myself a few questions. Or are we now to be told that a court must be given power by a legislature, and if it is not given that power, it must take it in the face of a legislative direction to the contrary? Of course as we all know there is a great deal of word-play and after all — we are, to some degree, word merchants. There's a great deal of word-play in all the discussion about section 96 , which is in terms an appointing power, and Professor Scott himself has told us that literal interpretation is the first resort. Well, now, apparently, literal interpretation seems to be subordinate to some higher constitutional imperative; and there's nothing wrong with that. Perhaps even courts do that occasionally, but what Professor Scott has done is to say that you can't be a Superior Court unless you are an agency or board or some tribunal that can determine without review elsewhere, except by appeal, your own jurisdiction. And then he also tells us that whenever any agency's authority is declared to be unreviewable, it must therefore be a Superior Court. Well, put me in the doubter's ranks, at least for the sake of argument. He isn't very clear whether this applies to federal agencies; perhaps section 96 is also a limitation on function as well as on form, and to be applied to federal agencies. I think my old friend Professor Lederman, in some writings of his that I remember, suggested that; I think it was probably, was it only in a footnote, Bill, or was it the text?

\section{["In the text, sir." (Lederman)]}

And he may still be of that opinion. But as for me, I think that all I can do is really reserve judgment. It would be very foolish for me to say anything else. But it is an important aspect of constitutional authority. Some of the more recent cases of the Supreme Court of Canada on the subject, which are well known to you, have tended, I think, to take a pretty generous view of the scope of provincial legislative power in that respect. Well, I think that I have probably exhausted all that I can decently, and if not decently, all that I ought prudently, to say. So let me thank you again for the opportunity to come once again to a Law Teachers meeting. When I will have the opportunity to come again, I do not know, but perhaps you may meet someday in Ottawa and it may be possible for me to either walk across the street, or not far away, and to join you again in your deliberations. 